\title{
Deuteronomic tithe laws and their humanitarian implications for Africa
}

\author{
Miracle Ajah \\ Stellenbosch University, South Africa \\ majah@noun.edu
}

\begin{abstract}
There has been no univocal position among scholars on the compatibility of the different codes for tithing, the number of tithe laws in the Old Testament, and the possibility of applying the Old Testament datum to contemporary Christianity. Driver, Wellhausen and Weinfeld see the tithe provisions in Deuteronomy as in "serious and indeed irreconcilable conflict" with other provisions in the Pentateuch, while McConville and Averbeck show that they are compatible. Although, the issue of compatibility of the number of tithe laws in the Old Testament may still be controversial, however, the theological significance of tithing at different times and places remains the same. The different contexts or traditions for the concept of tithing in the Old Testament, whether Priestly, Deuteronomic or Prophetic, present the greatest motivation for tithing as the worship of God. This paper re-examines selected verses from Deuteronomy 12, 14 , and 26 that focus on theological themes such as covenant relationship, reverence for God, obedience and blessing, fellowship and welfare. It argues that a theological interpretation of tithe laws in Deuteronomy in the light of humanitarian understanding can facilitate a better administration of law and justice in Africa.
\end{abstract}

Key words

Tithe law; justice; Deuteronomy; theological interpretation; Africa

\section{Introduction}

The tithe laws in the book of Deuteronomy presents some theological interpretations that can serve as an incentive for humanitarian emphasis in administration of law and justice in Africa. Tithing was a custom that dates back more than 3000 years and has been adopted today by some Christian denominations. In this practice, worshippers were expected to present 10 percent of their annual agricultural produce as an offering to God, which 
invariably was used for the maintenance of the cult and its personnel, and the less privileged in the community. The Book of Deuteronomy presents it as one of the ways of appreciating or acknowledging the LORD as the owner and giver of the Promised Land to the people of Israel (Deut 26:1-15). Since there was no clear distinction between secular and sacred in ancient Israel, tithing was one of the major means of upholding its institution both economically and spiritually. Hezekiah and Nehemiah, who at their times served as Israelite/Jewish leaders, saw disobedience to it as a threat to their spiritual and corporate existence as a nation (2 Chron 31:4-10; Neh 13:1012). Also, the prophet Malachi advocated for obedience to tithing law as a basic ingredient in God's covenant relationship to the human (Mal 3:6-12). Tithing was a serious obligation in the Old Testament and in the Mishna.

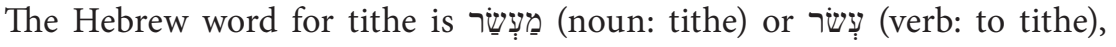
which means to give or take the tenth of everything. Wilson (1997:10351055) defines it as the religious act of giving a tenth for the support of a religious purpose. Tithing was an ancient and widespread practice. It was not peculiar to the Hebrews; but also found in religions and cultures other than those of Israel or the Semitic people (Weinfeld 1971:1155; Jagersma 1981:78-79).

Scholars have critically discussed the compatibility of the different codes that provided for tithing, and on the number of tithe laws in the Old Testament, and the possibility of applying the Old Testament datum to contemporary Christian Church. Deuteronomy's (D) provisions for tithes are found in Deuteronomy 12, 14 and 26, while Priestly's (P) laws are contained in Leviticus 27 and Numbers 18. What distinguishes D from $\mathrm{P}$ is the fact that P's tithe was given to the Levites and priests, while D's tithe included the giver and his family at the central sanctuary (Deut 12:17), with a concession for those who were living in distant places to convert it to money, using it to purchase anything they desired to consume at the central sanctuary (14:24-26). The tithe of P like that of D was associated with the Levites, but there was no mention of foreigners, widows and orphans participating in it. In an attempt to explain the differences, there is no consensus among scholars. ${ }^{1}$

1 For Driver (1895:169), the law in Deuteronomy is in "serious and indeed irreconcilable conflict" with that of P. His main area of worry is the issue of redeeming the tithe and adding one-fifth in $\mathrm{P}$, as against the commuting of tithe proceeds to money in D. He 
The issue of compatibility and number of tithe laws in the Old Testament may still be controversial but the theological significance of the institution at different times and places remains the same. The different contexts or traditions for the tithe concept in the Old Testament, whether Priestly, Deuteronomic or Prophetic, presented the worship of God as the greatest motivation for tithing, despite who the beneficiaries were. This paper reexamines selected verses from Deuteronomy 12, 14, and 26 that focus on theological themes such as covenant relationship, reverence for God, obedience and blessing, fellowship and welfare. It argues that a theological interpretation of tithe laws in Deuteronomy in the light of humanitarian understanding can facilitate a better administration of law and justice in Africa. Thus, the focus of this paper is in two parts: first, it reviews and presents a theological analysis of selected chapters in Deuteronomy, and second, it applies the theological analysis to humanitarian understanding in the administration of law and justice in Africa.

believes that the two accounts represent different stages or development in history and not one tithe practice. In the same vein, Wellhausen argued that by the time of $\mathrm{P}$, tithes became a little more than a tax due to the clergy, and a burden to the people, and were stripped of the excitement that characterized early Israelite religion in D (1994:156). For Wellhausen, it was $\mathrm{P}$ that changed the old custom of tithing which was a sacrifice of joy.

To the contrary, Weinfeld said that it was D instead, that made the whole tithe into something different from what it had previously been. He contended that the original purpose was the maintenance of the temple and its personnel (Weinfeld 1971:1160). Jewish traditional idea of a second tithe affirms Weinfeld's position that the tithes of Numbers and Deuteronomy are entirely incompatible with each other (McConville 1984: 71). Some scholars' opinion is that the tithing codes are compatible. Among them are Averbeck and McConville. According to Averbeck, "... the tithe passages in Pentateuch are not contradictory but complementary. In general, Numbers 18 (i.e. P) views the matter from the point of view of the Levites and Priests (their due from the people), but Deuteronomy 14 views it from the perspective of the nation as a whole, the common people, i.e., their responsibility to the Levites" (Averbeck 1997:1041). The tax character associated with $\mathrm{P}$ by Wellhausen, according to McConville, is discernible in Deuteronomy. "The author of Deuteronomy's law has in all likelihood, simply assumed tacitly that what was not consumed in the festival meal would go to the clergy" (McConville 1984: 74). Therefore, he affirms that the feast involvement of the offerer does not necessarily contradict its character as a temple tax. The author of D's law probably knew that of P; but it is not necessary to think that he made a radical break with the existing law. 


\section{A review of tithe laws in Deuteronomy}

The tithe laws in our chosen pericopes will be reviewed under three broad divisions: (a) Tithe and Offerings - 12:1-19, (b) The annual/triennial tithe 14:22-29, and (c) The tithe declaration - 26:12-15. The chief purpose of the tithe system in Deuteronomy was "that you may learn to fear the LORD your God always", and the effect was "so that the LORD your God may bless you in all the work you undertake” $(14: 23,29)$.

\section{(a) Tithe and offerings (Deut 12:1-19)}

In this text, tithing was one of the statutes and ordinances the children of Israel were to observe diligently when they occupied the "Promised Land." The tithe was to be taken to the place where the Lord would cause His name to dwell (vv. 5, 11, 18). The household of the payer (vv.12, 17, 18) ought not to eat it in any place he saw, but at the chosen place with joy; the Levites were to partake of it since they had no allotment or inheritance among the people (vv.12, 18, 19).

The Levites were not specifically mentioned as the recipient of the tithes in this text. Rather, they were invited to partake of it in conjunction with the household of the one bringing the tithe. This practice would be an obligation in the land the children of Israel were going to possess. Therefore, the motivation for tithing here is found in verse one: they were to observe the statutes and ordinances as obedience to the God of their ancestors, who gave them opportunity to occupy the land. The goods subject to tithe were grain, wine, oil and the firstlings of herd and flock (v.17).

\section{(b) The annual/triennial tithe (Deut 14:22-29)}

This law prescribed the setting aside of a tithe of all the yield of the seed from the field. The tithe was to be brought in yearly and eaten at the place chosen by God, (a symbol of dwelling for the Lord's name). If the distance were great, the tithe could be converted to money and brought to the chosen place to be spent on a festive meal, to be eaten by the payer's household. Every third and sixth year of each sabbatical cycle, the tithe would be kept in the local stores, for the benefit of the Levite, who had no land of his own, and the resident aliens, the fatherless, and the widow. The people were to pay the tithes so that "the Lord your God may bless you in all the work that you undertake" (14:29). Such assurances were given in connection with laws 
that required economic sacrifice for the sake of the poor (other examples include freeing the debtor servant after six years, lending to fellow Israelites without interest, and leaving overlooked sheaves, olives, and grapes for the poor to glean in Deut $15: 10,18 ; 23: 21 ; 24: 19-21)$. Lest the Israelite fear that these sacrifices would cause economic hardship, he was assured that, on the contrary, they would ultimately lead to greater prosperity. The effect of tithing on the payer was not economic hardship, but the blessing of the Lord which could not be quantified (see Mal 3:10-12). This understanding is re-echoed in 26:12-15, where the payer is admonished to pray for God's blessing of the land and the people of Israel.

The goods subject to tithe were grain, wine, oil, the firstlings of herd and flock (v.23). It was obligatory for the Israelites to pay the tithe yearly in order to demonstrate their reverence for God always and also that the Lord their God might bless them in all the work that they undertook (vv.23, 29). The text does not say when these offerings were to be brought to the sanctuary. It seems that the regular pilgrimage festivals were the most convenient occasion though farmers probably made private pilgrimages at other times too. The beneficiaries of the tithes included the household of the payer (in the festive meal), the Levites, the resident aliens, the fatherless, and the widow. It is not clear how the farmer and his household could consume the entire tithe during pilgrimages to the sanctuary. Tigay (1996:143) suggests that conceivably the law aimed to encourage farmers to travel to the sanctuary more often, but it would have been extremely difficult for those living far away to do so; that on the basis of 26:12, whatever was left over after three years had to be given to the poor. According to Tate (1973:153), "the account in Deuteronomy 14 seems quite idealized and leads one to suspect a web of traditions and customs that are not written but which regulated tithing."

\section{(c) The tithe declaration (Deut 26:12-15)}

Here, the law prescribed what the Israelites must do after they had fulfilled the law of tithing in the third year, referred to as the year of tithing. The phrase, "the third year, the year of the tithe" is puzzling, since tithes were given every year except the sabbatical year according to Deuteronomy. Hoffmann suggests two possibilities; first that the phrase reflects the farmer's perspective that only the third year is a tithe year, because only 
in that year must he give the tithe away; second, that the phrase means "every third year of the years in which tithe is given" (Tigay 1996:242). The second suggestion seems appropriate to the understanding of the phrase, because tithes were not collected on the sabbatical year. The tither would proclaim that he had given out the tithe to the Levites, the resident aliens, the fatherless and the widows, and not desecrated it by using it for impure purposes. The tither would then petition the Lord to "look down from your holy habitation, from heaven, and bless your people Israel and the ground that you have given to us, as you swore to our ancestors - a land flowing with milk and honey" (v.15).

This law created the impression that the beneficiaries of the tithe were the Levites, the resident aliens, the fatherless and the widows. The goods subject to tithe were "the tithe of your produce". There was no specific mention of the type of produce tithed. The aim of this law was to enable the Israelite to affirm that he had obeyed the commandments of the Lord (v.13), and to request His blessing (v.15).

As far as Deuteronomy is concerned, tithes were always related to a meal, and the beneficiaries of tithe included the household of the payer, the Levites, the resident aliens, the fatherless and the widows. ${ }^{2}$ According to Tigay ... "By requiring the owners to travel to the sanctuary and themselves eat the tithes Deuteronomy turned the tithes into a means of linking the laity to the sanctuary and providing them with religious experience there. By giving the tithes to the poor in some years, it met a humanitarian need as well" (Tigay 142). There was no clear difference between the priests and the Levites in the book of Deuteronomy. Apparently, Deuteronomy assigned to all Levites priestly functions, as understood from Deuteronomy 18:1, "The Levitical priests, that is, all the tribe of Levi." The later passages in Deuteronomy asserted that, besides serving in the temple and guard duty; the Levites were to keep the Deuteronomic torah in custody $(17: 18 ; 31: 9,24$ ff.). They were thus a gift from God to Israel, which was allied to the law itself. The function of the priests, whom God had given, was not only to

2 The occurrence of an Ugaritic verb 'shr' in connection with the description of eating and drinking is similar to the use of tithe in Deuteronomy (Jagersma 118). Also, Jagersma reported that a number of texts in late Babylonian literature considered the tithes as an offering or sacrificial meal. 
serve an altar, but to serve a law. They were teachers and preachers as well as officers of a cult, and in this teaching role they enabled Israel to enter the full enjoyment of life before God in the covenant of Horeb. The Levitical priests were to live from the revenues of the altar and sanctuary, which included firstfruits and tithes, etcetera.

\section{A theological interpretation of the tithe laws in Deuteronomy}

The Deuteronomic tithe system is anchored in the belief that the LORD is the owner of the land and has given it to the people for a possession. The demand to tithe invariably was a reminder to the giver that all that he/she possesses belongs to the LORD and has been given by the LORD. We disagree with Weinfeld's submission that whereas the tithe is always a tax or gift for the maintenance of the temple or its personnel in other codes, that in Deuteronomy, it is simply a philanthropic gift (Weinfeld 1971:1161). Taken thus, it would mean that the tithe law in Deuteronomy was not an obligation to the giver. But the impression we get in the book of Deuteronomy is that of an obligation placed on the giver because the LORD gave the possession. The social functions of tithes in Deuteronomy should not promote the generalisation that the tithe system is philanthropic. In Deuteronomy, just as in the codes before it, the tithes are assumed to be the property of the sanctuary and its personnel (including the social function of supporting the feast at the central sanctuary 14:23-26), and to be capable of being redeemed by the donor for money (in effect, substituting money for produce when the sanctuary is far from the giver). The tithe is never eaten at the giver's home, but at the feast in the central sanctuary. The implication here is that the tithe belongs to the sanctuary and not to the giver.

Subsequently, the theological obligations surrounding the tithe system in the book of Deuteronomy will be elaborated under the following headings: (a) Covenant relationship; (b) Reverence for God; (c) Obedience and Blessing; (d) Fellowship; and (e) Welfare.

\section{(a) Covenant relationship}

The covenant relationship with the LORD was the basis for tithing in Deuteronomy. The tithe declaration in chapter 26:13-15 clearly shows 
that the tithe was an important commandment to the Israelites based on their covenant relationship with the LORD. The people were chosen by the LORD out of all the nations of the earth $(10: 15 ; 14: 2)$. As a result, they were expected to be a holy nation, reverencing the $\operatorname{LORD}(14: 1,2,23)$. The covenant ceremony in Deuteronomy 26:16-19, which immediately follows the tithe declaration, and ends the stipulation section of the book of Deuteronomy (12-26), makes the concept of the uniqueness of the Israelite people obvious. Thus, the declaration in Deuteronomy 26:13-15 views the giving of tithe as an aspect of keeping the covenant by the Israelites. The giving of tithe to those fellow members of the covenant nation, who could not enjoy the land produce from their own fields, was thus important for the existence of Israel as a nation. This becomes evident in the justification of the Levites' portion in Deuteronomy 14:29, since they did not have a share in the land (Norrback 2001:223).

\section{(b) Reverence for God}

Another great motivation for the payment of tithe in Deuteronomy is the reverence for God - “... so that you may learn to reverence the LORD your God always" (14:23). According to Merrill, "Not to be overlooked is the fact that the underlying purpose for presenting the tithe was to instil within the Israelite a proper reverence for the Lord as the Sovereign, the one to whom he was ultimately accountable" (Merrill 1994:240). The Deuteronomic tithe (especially the annual tithe) was expected to be given at the central sanctuary on the occasion of an annual feast or pilgrimage. Distance was not supposed to constitute a problem in fulfilling this law, hence the admonition in vv. 24-25. One problem with the presentation of tribute such as cattle and other large offerings was the distance that must be covered between villages in remote parts of the land and the central sanctuary. To expedite matters the law permitted the conversion of the produce into money which then could be used to purchase the same goods upon arrival at the house of the Lord (vv. 24-25). This device did not relax the cultic requirement, since its effect was to enable the worshipper and his household to participate in the feast at the chosen place.

The aim of the various annual pilgrimages was to worship the LORD at the central sanctuary. Pundt (1989:7) reports that one of the ways the LORD used to remind the Israelites of the LORD'S presence was through (1) the 
annual Feast of Unleavened Bread (the Passover), (2) the Feast of Harvest (feast of weeks, feast of wheat-harvest or feast of the first-fruits), and (3) the Feast of Ingathering (or feast of tabernacles). On each of these occasions every Israelite was commanded to joyfully "appear before the Lord...not empty-handed. Every man shall give as he is able, according to the blessing of the Lord your God which the LORD has given you" (Deut. 16:16, 17; cf. Neh.8:9-12). Three times a year in particular, the children of Israel were to gather in the special presence of God and be reminded that it was God who had provided all that they had; and it was God who even provided for the means of those Feasts. Therefore, the tithe became the most quantifiable support that facilitated the programmes (cf. 2 Chron 31:7-10). This practical and perfectly legitimate way of making pilgrimage manageable continued into the New Testament times and, in fact, lies behind the gospel accounts of Jesus and the moneychangers (Matt 21:12-13; cf. John 2:13-16). Like any other concession of this kind, it was subject to abuse by those who, like the moneychangers, would profit from the exchange by charging exorbitant rates. The celebration of the tithe itself in a feast at the central sanctuary became a means by which Israel might learn to reverence the LORD (McConville 1997:19-36).

\section{(c) Obedience and blessing}

The Deuteronomic tithe contains both a call to obedience and the blessing that obedience brings. Blessing indeed is contained in the very act of obedience. For McConville (1997:19-36), "Here is, in essence, the moral order." The Deuteronomic tithe highlights the importance of obedience and self-denial in one's devotion to the LORD. It shows that the enjoyment of the land and God's blessings were dependent on the obedience. Some of the relevant texts that highlights this position are reviewed below:

- Chapter 26:13 views the giving of tithe as obedience to the commandment of the LORD:

Then say to the LORD your God: "I have removed from my house the sacred portion and have given it to the Levite, the alien, the fatherless and the widow, according to all you commanded. I have not turned aside from your commands nor have I forgotten any of them (Deut 26:13 NIV). 
- Chapter 14:23 sees it as a proof of reverencing the Lord:

Eat the tithe of your grain, new wine and oil, and the firstborn of your herds and flocks in the presence of the LORD your God at the place he will choose as a dwelling for his Name, so that you may learn to revere the LORD your God always (Deut 14:23 NIV).

- Chapter 14:29 presents the obedience to tithing as a means of receiving the LORD'S blessings:

So that the Levites (who have no allotment or inheritance of their own) and the aliens, the fatherless and the widows who live in your towns may come and eat and be satisfied, and so that the LORD your God may bless you in all the work of your hands (Deut 14:29 NIV).

- In another instance the tithe which appears in the context of other offerings and sacrifices is seen as a sign of doing what is good and right before the LORD, and securing the welfare of one's descendants:

Be careful to obey all these regulations I am giving you, so that it may always go well with you and your children after you, because you will be doing what is good and right in the eyes of the LORD your God (Deut 12:28 NIV).

McConville (1984:84) claims that, "one of the Deuteronomy's insistent themes, is that the enjoyment of the Promised Land depends upon Israel's devotion to the LORD and readiness to give (נֵָָן) in obedience and selfdenial." The giving demanded was a giving in return. McConville reports that the verb נתָתן (give) appears within the context of Deuteronomy 26:12-15 in greater concentration than anywhere else in the book, and the deliberateness of its use was to bring out the reciprocity between the gracious giving of the LORD and the giving required of Israel. As blessing is unthinkable without righteousness and or obedience, so is obedience unthinkable without blessing. This relationship illustrates the moral aspect of Deuteronomy's laws.

\section{(d) Fellowship}

Another peculiar characteristic of the tithe system in Deuteronomy is the idea of fellowship with the LORD and the community at the central sanctuary. The communal nature of the tithe on the occasion of offering it at the central sanctuary is clear from the concluding statement of 
Deuteronomy 14:26: "And you shall eat there before the LORD your God, and rejoice with your household." Merrill opines that this phrase strongly suggests that the Lord was more than an interested observer in what was going on (Merrill 241). The LORD was a participant, for such was the nature of banquets that accompanied the making and ratification of covenant relationships. The giver was expected to participate in the feast with the household, just as other families were expected to do.

Furthermore, this fellowship aspect of tithe in Deuteronomy has a strong social and ethical dimension. The unity of the people in worship knew no hierarchy or divisions. This depiction of the sacrificial activity is not concerned with the role of the priests; no king leads or represents the people. The "place" (הָָּּוֹם) is not a royal-sacral complex in which the people's right of approach is restricted or mediated. The place belongs to the LORD and to Israel. The gathering of households as demanded involved the inclusion of slaves, and the less privileged, in the big picture of the people of God, as well as the Levites, who have no substance of their own. It is unthinkable that they were to be left at home in the light of the specific provisions for them in the triennial tithe (14:28-29).

In spite of the clear recognition that Israel is a nation, living on the land given to it by God, the image that is presented is more of that of a family, or clan, than of a nation with all its mixed and varied elements. In consequence all Israelites are encouraged to think of themselves as "brothers" (cf. Deut. 14:7; 15:2, 3; Clements 1989:56). The term אָזָים, "brothers", is Deuteronomy's characteristic expression for referring to fellow-Israelites, regardless of social status or tribal divisions (e.g. Dt. 1.16; 3.18, 20; McConville (1984:84). As God's children, all Israelites are brothers and sisters with mutual obligations to care for each other. They are holy to the LORD and must shun all conduct that is incompatible with that status. They are God's treasured people. In return for their service, God promises to make them the most successful and pre-eminent people. Olson (1994:13) commented that, in contrast to the rampant illusion of individualism in much of contemporary society, Deuteronomy is passionately communal and relational. The individual is intimately tied to and interdependent in his or her relationship to God, to the community, and to the world at large. Deuteronomy deals with the wide variety of relationships - God's relationship to humans, human relationship within the faith community, 
and the relationship of human to creation. The tithe system was a major practical demonstration of the communal and relational nature of the book of Deuteronomy.

\section{(e) Welfare}

The triennial tithe provision in chapter 14:28-29 is remarkable. It is one of the best expressions of Deuteronomy's aim to create a society in which no one would be permanently disadvantaged, or consigned to a second-class status. Deuteronomy is otherwise realistic about the likely persistence of poverty ("since there will never cease to be some in need on the earth ..." Deut 15:11), even as Jesus remarked in Mark 14:7 ("For you always have the poor with you ..."). Here, the basic idea is not just 'charity', but the conferring of worth, dignity and belonging. Israel as paradigm for just societies is nowhere more powerful than here (McConville 1997:19-36). The inclusion of the 'foreigner' is surprising, in the context of a rationale that derives from Israel's holiness. The two appearances of the 'foreigner' in the tithe texts (cf. 26:12-13) make an interesting contrast; he is excluded from the dietary requirements, yet included in the provision for those without property. It is one of the points in which Deuteronomy's strict focus on Israel as the chosen people shows a propensity to give way to a more inclusive logic.

As suggested previously, it is not entirely clear what was meant by the triennial tithe. Most likely, what normally went to the Lord at the central sanctuary (Deut 14:22-27) was to go to the needy, including the Levites, every third year (Deut 14:28-29). One would still be giving to God by giving to God's people (cf. Matt 10:42; 25:40), so the significance of the tithe as tribute was in no wise diminished. This understanding is reinforced by the reference to the tithe in $26: 13$ as "the sacred portion", a term that suggests its exclusive ownership by the Lord (cf. Lev 5:15-16; 19:24; 27:28). Furthermore, the one who offered was to say, "I have removed from my house the sacred portion." Merrill (1994:270) suggested that the verb (ר) of consecrated things that belong to the LORD, means "to exterminate," that is, to totally separate what is God's from one's house so that it might be given to others. In Deuteronomy 26:12-15, the ordinance concerning the third-year tithe is related to the ceremony of covenant renewal at the Feast of First fruits (vv. 1-11), both by subject matter and juxtaposition. It 
mandated the setting aside of the tithe of the harvest of every third year for the purpose of meeting the material needs of the dependent of Israel including the Levite, the foreigner, the orphan, and the widow (v. 12). This was to reiterate the idea that the benevolence of God's people was to operate in two dimensions, the vertical and the horizontal. Thus, the offering of first fruits to the Lord (26:1-11) could not be separated from the beneficence to be shown to fellow kingdom-citizens (vv. 12-15).

Let it be remarked here that the Levites were not by definition poor neither were they widows, orphans or foreigners. Deuteronomy did not use any word for 'poor' in its laws relating to these classes. The aim of the law was to provide the Levites an alternative means to access Israel's wealth, in the absence of their control of land. They may not have had access, by their own right; to the court system either (cf. 10:18). Therefore, this law is not, properly speaking, a "welfare" provision; it rather ensured that these groups within society could participate fully in Israel's enjoyment of Yahweh's blessing, which is their entitlement as members of the holy people (McConville 1997:19-36).

In his view, Wright (1996:271) posited that the two explicit references to the Levites and foreigners (26:11-13) showed that the socially and economically deprived were not to be excluded either from the spiritual blessings of covenant worship or from the material blessings of covenant obedience. Thus, giving to the needy was not only a sacred duty to God, but it also was the defining point for any claim to have kept the law. The law is kept only if the poor are cared for. This shows the essential thrust of Old Testament ethics - that love for the neighbour is the practical expression of any claimed love for God. It also shows how the enacted love for the poor and needy is the practical proof of genuine, God-honouring love for the neighbour.

\section{Deuteronomic tithe laws: Humanitarian implications for Africa}

The theological interpretations of the Deuteronomic tithes present some invaluable lessons for the administration of law and justice in Africa. McConville (2003:377) opines that Deuteronomy supports an organised and dynamic system where everyone in the community is considered important. Examples abound in the New Testament where churches were 
admonished to make regular generous contributions for the impoverished church in Jerusalem (2 Cor 8:9). Thus, this section discusses some of the possible implications of the Deuteronomic tithe laws to Africa under the following headings: provisions for the community of faith, an appeal to work, socio-cultural implications, a caution against greed, and economic implications.

\section{(a) Provisions for the Community of Faith}

In the Old Testament, tithing provided support for the Levites, priests, and the less privileged in the community namely the widow, the orphan and the stranger. The contextual application of the tithe system in Africa would improve the material resources for the Church ministry. Church workers would be more devoted to duty because they would be properly taken care of (cf. 2 Chron 31:4-10; Neh 13:10-12). The poor and the less privileged in the community would be remembered and not forgotten. The Church's projects and missions would be executed without dependence on external resources. Missionaries would not be abandoned and mission fields would be maintained. "Food in God's house" would benefit everyone in the community of faith (Mal 3:10).

Suffice to say here that the Presbyterian Church of Nigeria has been able to achieve in few years what it could not achieve in more than a century of existence (1846-1989) because of the adoption of the tithe system and evangelistic awareness. For more than 140 years, the Church had only one or two synods; but since 1989, when the tithe system was adapted, to date, the Church has 11 large Synods with over 70 Presbyteries, and hundreds of parishes and congregations under them (PCN 2006:72-101). There would be no limit to what the Church in Africa could achieve in a few years if they adopted the tithe system. Virtually, every aspect of the life of the Church is dependent on its economic status. Evangelism, Church expansions and funding go hand in hand. The tithe system is a good economic base for the Churches, because it encourages growth in Christian stewardship.

In the Pentateuch, the religious community had a special responsibility towards the Sanctuary, the cult personnel and the poor. This experience is not strange to African communities either. It is said, "Any system that does not explicitly extend protection to the poor will stand condemned from a religious perspective" (Bosman 1991:255). Most African Churches 
are struggling to pay salaries of Church workers and build worship places, let alone care for the poor in their midst, because their members are not committing their resources sacrificially. If members would tithe their earnings to the Church - as the Pentateuch believing community was instructed to do - the care of the poor, the church workers, and Sanctuary would not be a problem.

\section{(b) An appeal to work}

Ancient Israelite society as presented in the Old Testament was an agrarian, subsistence economy. African communities are similar. Tithing is an appeal to work. The ancient Israelites were workers, so they tithed from the fruit of their labours. In the same vein, Africans should be workers and not beggars. Margaret Aringo supported this when she wrote (Aringo 2001:172):

According to African tradition, work creates self-satisfaction, respect, prestige, acceptance and wealth. All normal persons are expected to work. Laziness is not accepted. There is no dirty work and there is no work below human dignity.

Therefore, the modern African Church should challenge its members to appreciate the importance of working, as far as it is possible, whether in subsistence farming or in mechanized/industrialized sectors of the economy. In Aringo's words, "People are to direct their skills towards selfemployment where salaried jobs fail, and find joy in their task". According to Emmanuel Martey, "It is only when Africa is economically independent and interdependent that other races can give black Africans the respect that is due to them in a world where independence is governed by availability of capital" (Martey 1993:143).

In the Pentateuch, tithe was seen as a participation in God's blessings (Deut 14:29). The people who obeyed God in the Old Testament were blessed and they acknowledged it (2 Chron 31:10; Mal 3:10-12). Accordingly, religious leaders should educate their people that tithing does not impoverish any one; instead, it gives one an opportunity to participate in God's programmes and blessings. G.F. Hawthorne asserted that tithing was viewed as God's way of involving God's people, in God's own redemptive activity, in God's own immense concern for the poor and destitute. Just as God had shared 
God's blessings with God's people, those who received them must share with people less fortunate (Hawthorne 851-855).

\section{(c) Socio-cultural implications}

The tithe system was one of the best expressions of Deuteronomy's aim to create a society in which no one would be permanently disadvantaged, or consigned to a second-class status. The major thrust in Deuteronomic tithing was not "charity", but the conferring of worth, dignity and belonging, the paradigm for a just society. Within the context of sociocultural relationships, Deuteronomy preserved the holy status of the tithes by requiring that in most years they be consumed in sacral meals at the sanctuary, and by placing religious restrictions on how the tithe for the poor might be used (26:12-15). By requiring the givers to travel to the sanctuary and themselves eat the tithes, the Deuteronomic tithe system was a means of linking the laity to the sanctuary and providing them with community relationship and fellowship there. By giving the tithes to the poor in some years, it met a humanitarian need as well. In Tokunboh Adeyemo's contribution (Adeyemo 2006:231),

Generosity is not foreign to Africa; it is part of our culture. And we know that one does not need to be rich to be generous. We share what little we have. There is even a proverb, 'In friendship, even a crust of bread is shared.'

Through tithing, the unity and communality of the society was highlighted, especially in the book of Deuteronomy. All Israelites were encouraged to think of themselves as 'brothers' regardless of social status or tribal divisions (cf. Deut. 14:7; 15:2, 3). According to Clement (1989:56), "the offering of tithe became an act of wider significance than simply providing support for the ministers of Israel's worship and giving charitable assistance to the poor. It was a public expression of the religious good standing and law abiding faithfulness of the worshipper." The negligence of this practice would have had serious consequences on the communal principle. In the community, everyone is important; none should be neglected. Furthermore, the liturgical declaration in Deuteronomy 26:12-15 both reinforced the importance of the tithe as a sign of willingness to keep God's commandments in their full range, and it ensured that the tithe was not reduced to a mere optional extra that could be treated with indifference. 
The tithe system was a major practical demonstration of the communal and relational nature of the book of Deuteronomy.

\section{(d) Caution against greed}

There are indications in the Old Testament that people often failed to tithe (e.g. Neh 13:10-12); but there was also a reminder that the practice of tithing can be a substitute for real commitment. Amos 4:4 implied that people were faithful in tithing as though it were a substitute for faithful worship of God. Furthermore, their giving was not matched with a commitment to faithfulness within the community itself. Some lived in fine homes, had good incomes, and enjoyed cultured lives, but they were benefiting from a social structure that left many others impoverished (cf. 5:10-13; 6:4-6). They could afford to tithe and still be very well-off, and thus their tithing had become one of the ways they avoided God's lordship over their lives. It is imperative to note that tithing is not a substitute for mercy, justice and righteousness. Jesus' primary point in Matthew 23:23 was to criticize the scrupulous tithing of even few herbs grown in the backyard garden, if it were at the expense of fundamental issues of justice, integrity, and mercy. But one might have expected Jesus to say, "You should have practised the latter, and let the herbs take care of themselves" - or something equally dismissive. Instead, he said, "you should have practised the latter without neglecting the former."

In the Old Testament, giving the tenth to God did not mean that the ninetenths belonged to the individual, with the right to spend that anyhow. The tithe was an offering to show that all belongs to God. It provided the payer with a way of beginning the process of growth in the grace of giving. But the motives of tithing should be properly defined because it could be the source of pride (cf. Lk 18:11-14). Furthermore, the obligation in tithing was a theological one and not an ecclesiastical one, nor for a secular state to enforce as we have seen in the governmental use of religious offerings. Whether or not the individual responds to or adopts the tithe system is not the duty of the Church or the state to adjudicate. It is a matter of conscience.

The tithe system should not be understood as a manipulation of God or a magic wand to invoke God's blessings. If that is the only motivation then the tithe system must have been misunderstood. The blessing associated with tithing is the effect of obedience, which is measured not by the amount 
of material possession one has, but by the level of a person's understanding of God's grace and dealings in one's life. The "get rich quick" mentality has become the theology of many African Church leaders. The proliferation of Churches in the continent can be traced to the idea that it is the shortest way to freedom from poverty, and thus some leaders can manipulate the members for their personal benefits. It is difficult to work together these days because of such self-interest among the leaders. The Churches in Africa should realize that the call to tithe is not for the enrichment of the pastors or Church leaders. It is for the support of the propagation of the gospel, and the care of the less privileged in the believing community.

\section{(e) Economic implications}

Most governments in Africa do not fund religious bodies and their institutions. Most of them receive their funding through the support of their members and missionary agencies abroad (especially those which were planted by overseas missionaries). The withdrawal or the reduction of overseas support has affected some of the churches planted by foreign missionaries, and this can be seen in the way they do mission or embark on any major projects. This study encourages religious groups in Africa to consider mobilizing support or funding for their projects through local resources, thereby asserting their independence and self-respect. Several indigenous churches in Africa are funding their projects successfully through locally-generated resources, especially through the adoption of the tithe system. That is why many of them are overtaking some of the churches established by overseas missionaries, in Church planting, education, and leadership development. According to Mugambi (2003:103):

The dependence of African Churches and Christian Councils on development funds from their parent Churches abroad, have meant that their priorities were greatly influenced by the programme guidelines of the donors. These donors, in turn depended for the bulk of their funding on their governments. When the ideological priorities shifted in 1990 from Africa to eastern and central Europe, African Churches found themselves short of funds, unless they would embark on programmes for which funds were available ... Thus the involvement of African Churches in social transformation after the cold war has tended to be externally induced, rather than internally motivated. 
Religious groups in Africa should break the dependency syndrome as a law of nature. For example, when a child has grown up to adulthood, dependence on the parents is no longer tenable as a matter of course. Local ministries are best funded locally because God has adequately distributed resources around the world to fund God's kingdom locally. "Nku dia mba ehere mba nri" (Every community has what it takes to survive). ${ }^{4}$ The problem is rarely a shortage of money; it is usually a shortage of mature stewards (Roost 2006:13). Fund dependency has many adverse effects. It drains the energy of ministry leadership. They should consider the enormous energy wasted in drafting appeal letters and proposals to their overseas counterparts in order to solicit support. For instance, if they want to host a conference, they ask the overseas partners for funding; and if they want to buy a good vehicle for the officers of their governing body, they ask overseas partners to provide the money. Maintaining theological education and other institutions like health facilities and farms have always depended on what comes from abroad. If they must attend conferences abroad, or if some of their workers must be sent abroad for further studies and exposure, funding and sponsorship must be requested from the overseas partners. The question that agitates the mind is: for how long should this continue? External fund dependency cripples motivation. As long as Africans are depending on external funds, it will be difficult to develop mature stewards in it, and the potential for growth will be stifled. Worst of all, external fund dependency will continue to rob the nation of its prestige or dignity. It will lose respect because the one who pays the piper dictates the tunes.

The "Moratorium debate" is still fresh in our memory. John Gatu's controversial paper in 1970 (“Missionaries go home!") ${ }^{5}$ has continued to provoke interest and concern among emerging African scholarship

3 At this point we should recall the invaluable speech of M. Gandhi, "There is enough in the world to satisfy our need but not enough to satisfy our greed" (http://www.justiceafrica. org/postcard060105.htm).

4 This expression is usually employed by the Ohafia-Igbo (Nigeria) in reasserting the worth/ prestige of individuals and communities in different settings.

5 In the paper, John Gatu asserted the following: "We cannot build the Church in Africa on alms given by overseas Churches, nor are we serving the cause of the kingdom by turning all bishops, general secretaries, moderators, presidents, superintendents, into good enthusiastic beggars, by always swinging the tune of poverty in the Churches of the Third World. Let the mission be the mission of God in the third world, but not of the West to the Third World." 
(Gatu 1971:70-72). His focus was on the question: "why are mainstream African Churches unable to assert themselves in ecumenical foray?" He traced the cause of this shortcoming to the domination of such Churches by missionary personnel and funds. He suggested therefore that the missionaries should withdraw themselves and their funds, so that African Churches could cultivate their own self-understanding without the tutelage of foreign missionaries and mission boards. A host of other African scholars have expressed their discomfort on the dependency syndrome of African Churches. E.M. Uka wondered why Africa was still so dependent on western churches and other agencies after over a century of missionary enterprise in Africa (Uka 1989:252). His emphasis was on changed relationships, and not on cessation of relationships. Furthermore, Ogbu U. Kalu posed a similar question, "Why are churches in Africa... still needing to climb on someone else's shoulders to watch the parade" (Kalu 1975:15-16). He argued that Africa's problem is not genetic nor the product of a non-viable environment, but that of a victim of exploitation and political enslavement. The end products were Churches which could not stand on their feet, and a relationship which made aid the glutinous agent for maintenance of a dependent relationship.

Apparently, the call, "Missionaries go home”, was heeded by the year 2000. In most of the mainline Churches in Africa in the $21^{\text {st }}$ century, the majority of foreign missionaries have relocated to Eastern Europe and Asia, taking along with them their funds. Rather surprisingly and unfortunately, however, most mainline Churches in Africa now wish they had remained, or at least left the funding behind. This could explain why some Church leaders in Africa have devised new methods of soliciting funds from their old founders.

In the light of the aforementioned facts, religious groups in Africa have to face the challenge of generating their funding or resources locally, equipping themselves for relevant ministry in a rapidly changing continent. They need a new understanding of stewardship. Some of the greatest expansions of religion have taken place without external funding, for example, China in 1949 and South Korea, today (Roost 2006:14). External dependency perpetuates the mind-set of poverty and loss of ownership, and also encourages a preoccupation with external sources. Foreign funding creates a vulnerability to foreign economy. It means dependence 
on a single source. Foreign funding removes from the local people the potential to grow as stewards and lack of ownership takes away the dignity of local individuals. Finally, foreign dependency violates the "three self" principle - self-governing; self-supporting; and self- propagating. The theological interpretation of tithing is an appeal to mobilize funding for the ministry through local resources, and a guide to where to begin that process.

The tithe system is a call to believers to serve their God at a significant cost to themselves, and not at the expense of others. This religious understanding was very common among the Ohafia-Igbo, as exemplified by the saying, "Madu anigh ele anya isi utara ebe otuyighi ji" (One should not expect to reap from where he/she did not sow). Ifesieh (1989:256) informed us that in Igboland (Nigeria), gifts were presented to God in the form of sacrifices and offerings. The priests, who received these gifts, offered a token to the gods, and fed from the rest. Among the Ohafia-Igbo, during annual festivals like New Yam, families were expected to offer a portion of their agricultural produce for a communal meal in their compound shrines. The community believed that the gifts, sacrifices and communal meals would appease the gods, and guarantee a fruitful harvest the following year. There was no clear-cut numerical proportion like the tithe, but the worshippers saw the sacrifices and offerings as a theological obligation. The gifts, to a great extent, had to be valuable and at a significant cost to the giver. Perhaps, the reason why most mainline Churches in Africa found it difficult to fund their programmes was because the missionaries who established their churches did not involve members in funding the Church projects from the beginning. Therefore, they did not realise their theological obligation to support the Church financially. They felt that the Church was a place to receive and not a place to give, and so they relaxed into complacency.

The tithe system is an appeal to the African to reassert in Christianity the merits of the theological obligation he/she once had in the support of the traditional religion. In a sacrifice, something valuable to the worshipper is forfeited in African traditional religion and culture. Until the mainline Churches begin to see tithing as one of the sacrifices they are to make (or a regular percent to forfeit) for the cause of the gospel, funding major projects and missions may still be an illusion. 


\section{Conclusion}

The tithe law in Deuteronomy was based on the idea that the LORD is the owner of the Promised Land and had given it to Israel as a possession. Deuteronomy presented the tithe as a theological obligation and not as a philanthropic gift (26:13). Thus, the demand to tithe invariably was a reminder to the giver that all that he/she possessed belonged to the LORD and had been given by the LORD. The covenant relationship with the LORD was the basis for this demand. There is no reference anywhere in the text requiring the foreigner, who had no covenant relationship with the LORD to tithe. The underlying purpose for presenting the tithe was to instil within the Israelite a proper reverence for the Lord as Sovereign, the one to who all were ultimately accountable.

One of the Deuteronomy's insistent themes, was that the enjoyment of the Promised Land depended upon devotion to the LORD and readiness to give (נָָתֵן) in obedience and self-denial. Obedience and blessings went together in Deuteronomy $(12: 28 ; 14: 28,29)$. Furthermore, the fellowship aspect of the Deuteronomic tithe had a strong social and ethical dimension. All Israelites were encouraged to think of themselves as 'brothers' (cf. Deut. 14:7; 15:2, 3). The term אָזָים, 'brothers', was Deuteronomy's characteristic expression for referring to fellow-Israelites, regardless of social status or tribal divisions (e.g. Deut. 1.16; 3.18, 20). In contrast to the rampant individualism in much of contemporary society, Deuteronomy was passionately communal and relational.

Finally, the tithe system was one of the best expressions of Deuteronomy's aim to create a society in which no one would be permanently disadvantaged, or consigned to a second-class status. Deuteronomy was otherwise realistic about the likely persistence of poverty, "since there will never cease to be some in need on the earth ..." (Deut 15:11), even as Jesus remarked in Mark 14:7, "For you always have the poor with you ..." The major thrust in Deuteronomic tithing was not "charity", but the conferring of worth, dignity and belonging - the paradigm for a just society. 


\section{Bibliography}

Adeyemo, T (ed) 2006. "Generosity and Solidarity: Deuteronomy 14:2215:2.” Africa Bible Commentary: A One-Volume Commentary written by 70 African scholars. Nairobi: Word Alive Publishers.

Aringo, M 2001. "Work in the Old Testament and in African Tradition: Implications for Today," in Mary Getui, et al (eds) 2001. Interpreting the Old Testament in Africa. New York: Peter Lang.

Averbeck, R E 1997. sv שฺׁูุ. NIDOTTE 2, 1035-1055.

Bosman, HL, Gous, IGP \& Spangenberg, IJJ (eds) 1991. Plutocrats and Paupers: Wealth and Poverty in the Old Testament. Pretoria: J. I. Van Schaik.

Clements, R E 1989. Deuteronomy. Sheffield: JSOT.

Driver, S R 1895. A critical and exegetical commentary on Deuteronomy. Edinburgh: Clark.

Gatu, J 1971. "Missionary, Go home!” The Church Herald, Nov 5, 1971.

Hawthorne, G F 1986. sv “Tithe”. NIDNTT 3, 851-855.

Ifesieh, E.I. 1989. Religion at the Grassroots: Studies in Igbo Religion.

Enugu: Forth Dimension Publishing Company.

Jagersma, H 1981. “The tithes in the Old Testament," in Albrektson, B, et al (eds), Remembering all the way. A collection of Old Testament studies published. Leiden: Brill, 116-128.

Kalu, O U 1975. "The Peter Pan Syndrome: Aid and Selfhood of the Church in Africa." Missiology 3. Pasadena: American Society of Missiology.

M E Tate, M E 1973. “Tithing: legalism or benchmark?” Review-andExpositor 70, 153.

Martey, E 1993. African Theology: Inculturation and Liberation. New York: Orbis Books.

McConville, J G 1984. Law and theology in Deuteronomy. Sheffield: JSOT.

McConville, J G 1997. “Deuteronomistic Theology”. NIDOTTE 4, 528-537. 
McConville, J G 2002. Deuteronomy. Leicester: Apollos.

McConville, J G 2007. “Deuteronomy,” Life Application Study Bible (NLT), 2nd Ed. Carol Stream, Illinois: Tyndale House Publishers, Inc.

Merrill, E H. 1994. Deuteronomy. Nashville: Broadman \& Holman.

Mugambi, J N K 2003. "African Churches in Social Transformation," Journal of International Affairs, vol. 50(1), 103.

Norrback, A. 2001. The Fatherless and the widow in the Deuteronomic covenant. Abo: Abo Akademi University Press.

Olson, D T 1994. Deuteronomy and the death of Moses: a theological reading. Philadelphia: Fortress.

PCN 2006. The Presbyterian Church of Nigeria, General Assembly Diary. Calabar: Hope Waddell Press.

Pundt, G. A. 1989. “The Tithe.” Arizona-California District Pastoral Conference, Phoenix, AZ, pp. 1-15.

Roost, C 2006. A Growing Steward. Grand Rapids: International Stewards.

Tigay, J H 1996. Deuteronomy. JPS Torah Commentary.

Uka, E. M 1989. Missionaries go home? A sociological interpretation of an African response to Christian missions: A study in sociology of knowledge. Bern: Lang.

Weinfeld, M 1971. sv 'Tithes'. EJ 15, 1155-1163.

Wilson, J C 1992. sv “Tithe”. ABD 6, 578-580.

Wright, C J H 1996. Deuteronomy: based on the New International Version (NIBCOT 4). Peabody: Hendrickson. 